\title{
MACHINE LEARNING FOR MAPPING SPATIAL DISTRIBUTION OF THICKNESS AND CARBON STOCK OF TROPICAL PEATLAND BASED ON REMOTE SENSING DATA: A CASE STUDY IN LAKE SENTARUM NATIONAL PARK, INDONESIA
}

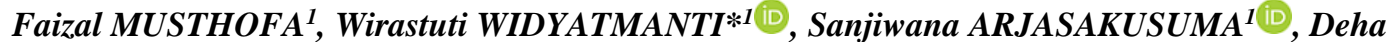 \\ A. UMARHADI ID Demetria A. PUTRI ${ }^{2}$, Fahrudin F. RAHARJA ${ }^{3}$, and M. K. ARRASYID
}

DOI: 10.21163/GT_2022.171.04

\begin{abstract}
:
Indonesia is one of the countries with the largest area of tropical peatlands in the world. These wide peatlands have a vital role in the carbon cycle and carbon storage in huge quantities, thus strict conservation in the area is necessary. One effort to carry out conservation is to understand the spatial distribution of carbon stock in peatlands. This study aims to map the spatial distribution of carbon stock based on peat thickness modeling using machine learning algorithms, i.e., Random Forest (RF), Quantile Regression Forests (QRF), and Cubist. A case study was conducted in a part of Lake Sentarum National Park, Indonesia where human interference is still limited. Digital elevation model (DEM) and synthetic aperture radar (SAR) data were included as the input variables. The results showed that RF performed the best among other models to estimate peat thickness (mean $=1.877 \mathrm{~m}$ ) with an RMSE (root mean square error) of $0.483 \mathrm{~m}$ and an $\mathrm{R}^{2}$ of 0.786 . DEMs are the most important parameters in our analysis compared to SAR data. Based on the best model, we estimated the total volume of $5,112,687 \mathrm{~m}^{3}$ in the study area, produced at $12.5 \mathrm{~m}$ resolution, which was then converted to a total of carbon stock at $0.337 \pm 0.106 \mathrm{Mt}$ carbon.
\end{abstract}

Key-words: Peat thickness, Carbon stock, Machine learning, Remote Sensing, Tropical peatland.

\section{INTRODUCTION}

The role of tropical peatlands is vital in the global carbon cycle considering their immense carbon-rich ecosystems (Dargie et al., 2017; Page et al., 2011). Ninety percent (404.5 Mha) of peatlands worldwide are located in boreal and temperate zones (Yu et al., 2010), however, the carbon content of tropical peatlands is greater than high latitude peatlands (Bourgeau-Chavez et al., 2018). Thus, tropical peatlands could store up to $104.7 \mathrm{GtC}$ from their limited coverage (90-170 Mha) (Ribeiro et al., 2021). Nearly half of tropical peatlands are situated in South-East Asia (43\%; 24.8 Mha) (Dargie et al., 2017; Page et al., 2011). Tropical peatlands are widely distributed in three major Indonesian islands including Sumatra, Kalimantan, and Papua, with a total area of 13.43 Mha (Anda et al., 2021). This area undoubtedly provides carbon storage in a huge quantity (Mitra et al., 2005), while on the other hand, it has a large potential as a carbon emission source due to the conversion to agricultural and plantation purposes (Umarhadi et al., 2021).

\footnotetext{
${ }^{1}$ Department of Geography Science Information, Faculty of Geography, Universitas Gadjah Mada, Indonesia, faizal.musthofa@mail.ugm.ac.id, Correspondingauthor* ${ }^{*}$ widyatmanti@ugm.ac.id, sanjiwana.arjasakusuma@ugm.ac.id, deha.agus.u@mail.ugm.ac.id

${ }^{2}$ Faculty of Forestry, Universitas Gadjah Mada, Indonesia, demetriaalika2018@mail.ugm.ac.id

${ }^{3}$ Department of Mechanical Engineering, Vocational School, Universitas Gadjah Mada, Indonesia, fahrudinfirda@mail.ugm.ac.id

${ }^{4}$ Department of Economy, Faculty of Economy and Bussines, Universitas Gadjah Mada, Indonesia, arrasyid103@gmail.com
} 
Tropical peat formation is mainly resulted from the accumulation of decomposed rainforest plant debris (branches, leaves, roots, and trunks) for million years (Rieley \& Page, 2016), leading to the abundance of carbon content and thus considered as organic soils. The development of peatlands in South-East Asia started in the Pleistocene era (26,000 yr BP) for the inland peatlands (Page et al., 2004), followed by the formation in the coastal and sub-coastal area in the Holocene period $(5,000$ $6,000 \mathrm{yr}$ BP) (Supardi et al., 1993). The accumulation process continues to form a dome where is bordered by the sea, rivers, and/or in the depression area enclosed by levees (Melling, 2016). The mound of peat dome is indistinct in a gradient of about $1 \mathrm{~m} \mathrm{~km}^{-1}$ on the surface with higher elevation toward the center of the dome (Anderson, 1964). This indicates the thickness of peat is related to the higher accumulation, hence it stores a larger amount of carbon.

Considering the importance of peatlands, mapping the distribution of peat thickness and soil carbon stock is a part of efforts to mitigate disasters and climate change, especially in reducing carbon emissions. Moreover, the governance on peatlands is based on peat thickness whether it can be used for cultivation or should be fully conserved, with a threshold of $3 \mathrm{~m}$ thickness in Indonesia (Dohong et al., 2018). The most common method to spatially predict peat thickness is geostatistics by interpolating the thickness or depth data collected in the field (Altdorff et al., 2016; Jaenicke et al., 2008; Keaney et al., 2013; Silvestri et al., 2019), however, the density and distribution of samples highly influence the results. Spatial modeling has been utilized taking the high correlation between peat thickness and surface elevation using empirical methods such as linear regression (Holden \& Connolly, 2011), yet it is challenging to accommodate the elevation variability of the underlying mineral substrate (Silvestri et al., 2019). The use of multivariate data coupled with machine learning methods can achieve an accurate peat thickness estimation and allow the evaluation of variables' importance in the modeling (Rudiyanto et al., 2018).

Previous research explored the prediction of peat thickness using 14 machine learning models based on environmental variables including elevation, terrain parameters, and distance from rivers and/or sea, as well as radar and optical satellite imageries in Bengkalis Island, where vast peat degradation peatland has occurred (Rudiyanto et al., 2018). The variables used considered the factors contributing to the development of soils that consist of peat properties, organisms including human activities, relief, and geographical position (McBratney et al., 2003; Rudiyanto et al., 2018). Our study demonstrated peat thickness estimation in undisturbed peat swamp forest in Lake Sentarum National Park, Borneo Island. We adopted the previous study by exploring multi variables and evaluating machine learning methods (i.e., Random Forest, Quantile Regression Forest, and Cubist) to produce high-resolution peat thickness $(12.5 \mathrm{~m})$. Moreover, spatial information of carbon stock was derived based on peat thickness, bulk density, and carbon content.

\section{STUDY AREA}

Lake Sentarum National Park (LSNP) is a national park in the middle of Borneo Island, Indonesia, located in the floodplain of Kapuas River upstream. Peat swamp forest covers $16 \%$ of the national park and is considered one of the oldest Indonesian peat swamps alongside Putussibau peatlands (> 30000 yr BP) (Anshari et al., 2001; Giesen \& Anshari, 2018; Ruwaimana et al., 2020). The study was conducted in the Kerinung Forest (3,627.93 ha; $0^{\circ} 43^{\prime} 48^{\prime \prime}-0^{\circ} 49^{\prime} 4.49^{\prime \prime} \mathrm{N}$ and $112^{\circ} 1^{\prime} 24^{\prime \prime}-$ $\left.112^{\circ} 21^{\prime} 54^{\prime \prime E}\right)$ of LSNP, just about $100 \mathrm{~km}$ northward from Equator line. This work focused on the smaller area in Kerinung Forest with a total area of 272.3 ha $\left(0^{\circ} 45^{\prime} 211^{\prime \prime} \mathrm{N}\right.$ and $\left.112^{\circ} 1^{\prime} 49^{\prime \prime} \mathrm{E}\right)$ as shown in Fig. 1.

As a basin, the water sources to LSNP flow from hills and plateaus in the surroundings. Temperatures range from $25^{\circ} \mathrm{C}-44^{\circ} \mathrm{C}$ with rainfall between $3000-5000 \mathrm{~mm}$. Soil types in the LSNP are generally divided into two large groups, namely sediments and organosols on land and sand and clay in hilly areas (Giesen, 1987). The level of peat maturity in Kerinung Forest consists of various levels including fibric, hemic, and sapric. 

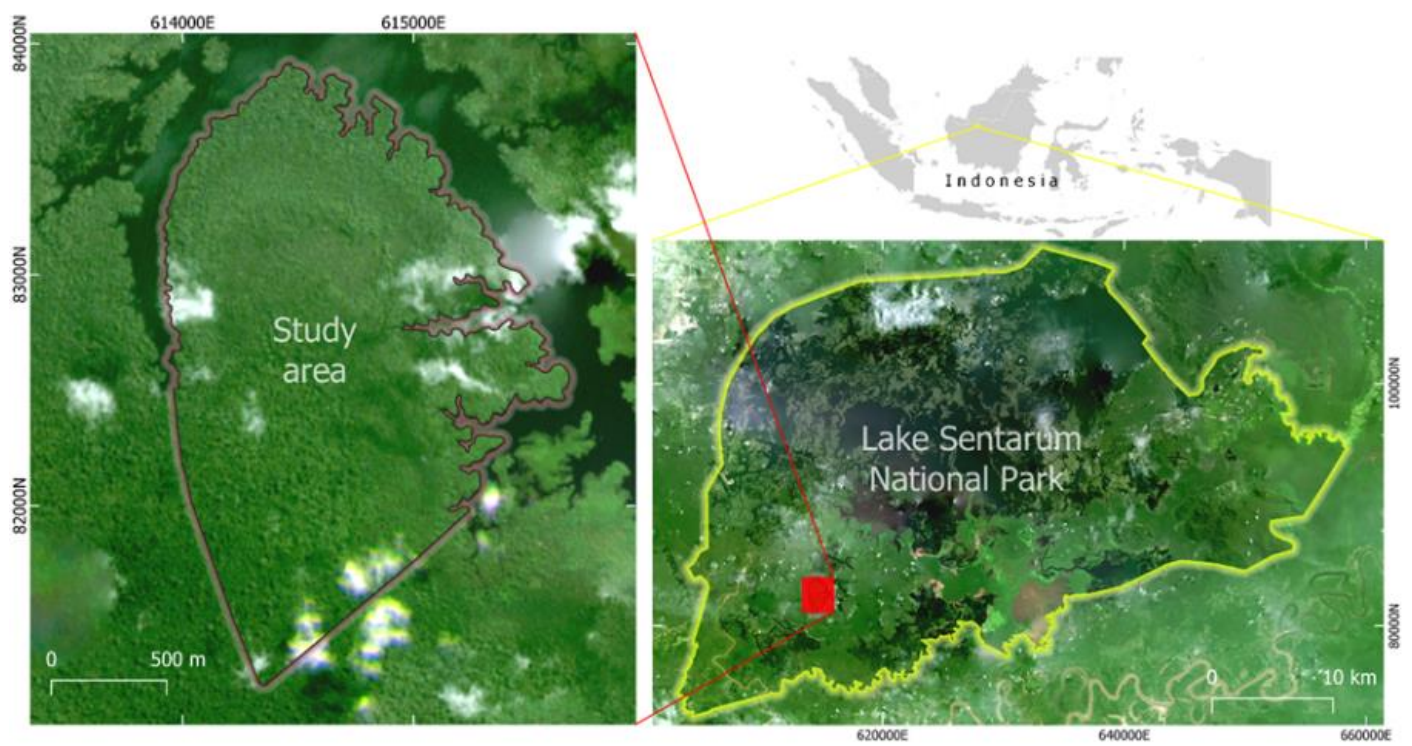

Fig. 1. Study area located in Kerinung Forest inside Lake Sentarum National Park, Indonesia. Planet(C imagery is used for the visualization.

\section{MATERIALS AND METHODS}

\subsection{Field Data}

Peat thickness data in the field were collected using peat soil drilling tools on 7-17 September 2019. Samples were determined by a transect method with a gap of $200 \mathrm{~m}$ between each plot. A total of 36 sites were plotted and the measurement was conducted 4-9 times in the center of the plot and surroundings to cover 236 samples in total. The number of repetitions is based on consideration of the thickness of the peat and the time taken for sampling. The deeper the peat thickness, the less the sampling repetition. A handheld Garmin GPSMAP 64s receiver was used to obtain the coordinates for each sample point by a single point positioning. GPSMAP $64 \mathrm{~s}$ receives locations obtained from GPS and GLONASS at high sensitivity with a quad-helix antenna (https://www.garmin.com/enUS/p/140022). The device can provide a horizontal accuracy of up to $3 \mathrm{~m}$ (Hil, 2020).

\subsection{Spatial data}

We refer to Rudiyanto et al., 2018 for parameter selection used in peat thickness modeling. This study used the parameter of elevation and synthetic aperture radar (SAR) images as both data contributed the highest in the estimation (Rudiyanto et al., 2018).

\subsubsection{Elevation data}

Digital elevation model (DEM) is one of the crucial parameters in modeling the thickness of peat (Rudiyanto et al., 2018) because the surface of the elevation model can determine the location where the peat dome is known (Jaenicke et al., 2008). The thickness can be generally figured out from the shape of the peat dome, showing that the closer to the peat dome, the deeper the thickness is. We used DEMs retrieved from two sources, i.e., Indonesian National DEM (DEMNAS) and ALOS DEM. DEMNAS is a high resolution $(8.25 \mathrm{~m})$ national elevation dataset compiled from TERRASAR-X (5 $\mathrm{m}$ ), Airborne Interferometric Synthetic Aperture Radar (IFSAR; $5 \mathrm{~m}$ ), and ALOS PALSAR (11.25 $\mathrm{m}$ ), added with stereo-plotting data (Geospatial Information Agency, 2018). In the study area, IFSAR acquired in 2005 was used as the source of DEMNAS. ALOS PALSAR (Advanced Land Observing Satellite-Phased Array-Type L-Band Synthetic Aperture Radar) Radiometrically Terrain Corrected (RTC) DEM was also used that has a spatial resolution of $12.5 \mathrm{~m}$. 


\subsubsection{Synthetic aperture radar data}

Synthetic aperture radar (SAR) images used in this study consist of two different sensors, i.e., Sentinel-1 and ALOS PALSAR, representing C and L-band, respectively. Sentinel-1 works at a frequency of $5.405 \mathrm{GHz}$ (wavelength $=5.6 \mathrm{~cm}$ ), capturing the same location on Earth's surface frequently every 6 days, thanks to its satellite constellation: Sentinel-1A and Sentinel-1B. The images were obtained from the Alaska Satellite Facility (ASF) Distributed Active Archive Center (DAAC) services and Google Earth Engine (GEE) cloud computing platform acquired in 2019. The images fetched from ASF DAAC were at Radiometric Calibration of S-1 Level-1, while images from GEE were provided at terrain correction level. ALOS PALSAR has a longer wavelength $(24 \mathrm{~cm}$; frequency $=1.27 \mathrm{GHz}$ ) than Sentinel-1. The image is freely available downloaded from ASF DAAC with an acquisition time in 2011. Both Sentinel-1 and ALOS PALSAR respectively provide dual-polarization (VV-VH and HH-HV) with a slight difference of spatial resolution (10 and $12.5 \mathrm{~m}$ ). Supplementing the individual polarization, some image transformations were also included, i.e., ratio, mean, and difference (Table 1). The total spatial data inputs used for the modeling are 13 image layers.

Table 1.

Equations of image transformations used for Sentinel-1 and ALOS PALSAR.

\begin{tabular}{|l|l|l|}
\hline Image transformation & Sentinel-1 & ALOS PALSAR \\
\hline Ratio & $\mathrm{VV} / \mathrm{VH}$ & $\mathrm{HH} / \mathrm{HV}$ \\
\hline Mean & $(\mathrm{VV}+\mathrm{VH}) / 2$ & $(\mathrm{HH}+\mathrm{HV}) / 2$ \\
\hline Difference & $\mathrm{VV}-\mathrm{VH}$ & $\mathrm{HH}-\mathrm{HV}$ \\
\hline
\end{tabular}

\subsection{Peat thickness modeling}

The methods used to obtain a peat thickness model are divided into several machine learning regressions. These algorithms include Random Forest (RF) (Breiman, 2001), Quantile Regression Forests (QRF) (Meinshausen, 2006), and Cubist (Kuhn et al., 2021) - all of them is non-parametric regression methods. Non-parametric regression is getting more prominent to describe geographical phenomena using Earth observation data and it has the capability to deal with non-linear complexity, however, it may allow overfitting the training dataset (Houborg \& McCabe, 2018; Verrelst et al., 2015). RF is a tree-based ensemble learning method that the results are generated from the aggregations of numerous classifiers (Liaw \& Wiener, 2002). Many bootstrap samples are firstly drawn from the given training dataset, then a tree is evolved by the bootstrap sample with modifications: at each node, randomly sample $m_{t r y}$ (number of random variables in each tree) of the predictors and choose the best split from among those variables (Liaw \& Wiener, 2002). QRF is the generalization of the random forest by modeling the conditional quantiles of an outcome of interest as a function of covariates without an assumption of normal distribution (Meinshausen, 2006; Wei et al., 2019).

Cubist is a rule-based regression based on the Model Tree approach according to the works by (Quinlan, 1992) and (Quinlan, 1993). The tree grows where the endpoint leaf contains a linear regression model (Kuhn et al., 2021; Zhou et al., 2019). Then a series of "if-after-after" rules are created, where the rule has an associated multivariate linear model, afterwards, the value is predicted from the corresponding model after the set of covariates satisfies the conditions of the rule (Zhou et al., 2019).

The performance of the three machine learning methods has been tested and achieved considerable accuracy to map tropical peat thickness (Rudiyanto et al., 2018). Field data of peat thickness were used as the reference which was then split into training (80\%) and test samples (20\%). Training data were used for peat depth modeling, while test data were to test the performance of the model developed from training data. The performance of modeling was evaluated using 10 -fold crossvalidation. 
All processing was conducted using RStudio with Caret Package that provides numerous machine learning methods including those used in this study, i.e., RF, QRF, and Cubist. Variable importance was also calculated describing the calculation of the relationship between the predictor and outcome by individually permuting individual predictor and assessing the effect when the corresponding predictor is negated (Kuhn \& Johnson, 2013). The importance score is relative, where the first (most important) variable is scaled to have a maximum value of 100 and the others range between 0 and 100. The score approaching 100 indicates the closeness to the first variable, and vice versa. Peat thickness models were evaluated using K-Fold Cross Validation to measure the coefficient of determination $\left(\mathrm{R}^{2}\right)$ and root mean square error (RMSE) values in order to find the best model.

\subsection{Carbon stock calculation}

To generate the spatial distribution of carbon stock, it is necessary to derive a map model of peat thickness with the best model result. The value of carbon stock is calculated based on the algorithm as follows:

$$
\mathrm{C}_{\text {stock }}=\mathrm{C}_{\mathrm{v}} \times \mathrm{V}
$$

where $\mathrm{C}_{\text {stock }}$ denotes carbon stock $(\mathrm{Mg}), \mathrm{C}_{\mathrm{v}}$ denotes carbon density $\left(\mathrm{Mg} \mathrm{m}^{-3}\right)$, and $\mathrm{V}$ denotes volume $\left(\mathrm{m}^{3}\right)$.

Volume is a multiplication thickness $(\mathrm{m})$ and between area $\left(\mathrm{m}^{2}\right)$, where the area is calculated based on the pixel size of raster data $(12.5 \times 12.5 \mathrm{~m})$. Thickness is obtained from the best model based on the accuracy comparison of the results of machine learning algorithms. Carbon density used in this study refers to a field measurement by Warren et al., (2012) conducted in 4 sites of LSNP. The carbon density is $0.0659 \pm 0.0208 \mathrm{Mg} \mathrm{m}^{-3}$, resulted from the multiplication between carbon content $(50.7 \pm$ $2.2 \%$ ) and bulk density $\left(0.131 \pm 0.043 \mathrm{Mg} \mathrm{m}^{-3}\right.$ ) (Warren et al., 2012).

\section{RESULTS AND DISCUSSION}

\subsection{Peat thickness models}

A total of 13 variables for the inputs of machine learning algorithms are presented in Fig. 2. In general, the inputs consist of elevation (2 variables), backscatter values (6 variables), and SAR image transformation (5 variables). Field data of peat thickness were used for reference in the learning process. The total of field samples is 237 , i.e., 190 samples (80\%) for modeling and 47 samples (20\%) for testing. The input variables and training sample for references were processed using three machine learning regressions: RF, QRF, and Cubist, and evaluated using 10-fold cross-validation.

The results of peat thickness modeling are shown in Fig. 3. Visually, three models have similar spatial distribution, showing the thicker peatlands in the middle and south of the study area, while lower thickness towards the edge of the dome. However, some thicker peats were found between thinner peats, showing that the thickness is not always gradual following the relative position to the edge. For more detail, Cubist model showed the patchy areas for high thickness. As shown in Fig. 4, high thickness values are observed in Cubist model, showing the potential of overestimation. Overall, the mean values of RF and Cubist models are similar, i.e., 1.877 and $1.816 \mathrm{~m}$, respectively. The mean value of QRF model is lower $(1.640 \mathrm{~m})$, indicating the underestimated values.

The accuracy of the models was assessed using coefficient of determination $\left(\mathrm{R}^{2}\right)$ and RMSE (Table 2). The RMSE value is related to the corresponding $\mathrm{R}^{2}$ of each model. RF outperformed the other two algorithms with an RMSE of $0.483 \mathrm{~m}$ and $\mathrm{R}^{2}$ of 0.786 , followed by QRF model (RMSE $=$ $\left.0.544 \mathrm{~m} ; \mathrm{R}^{2}=0.729\right)$. The accuracy of Cubist is significantly lower than the other two models with an RMSE of $0.756 \mathrm{~m}\left(\mathrm{R}^{2}=0.514\right)$. As likely other tree model approaches, overfitting problems may occur in Cubist model as well (Noi et al., 2017), despite several studies also reporting its outperformance compared to other methods (Dias et al., 2021; Houborg \& McCabe, 2018; Zhou et al., 2019). 


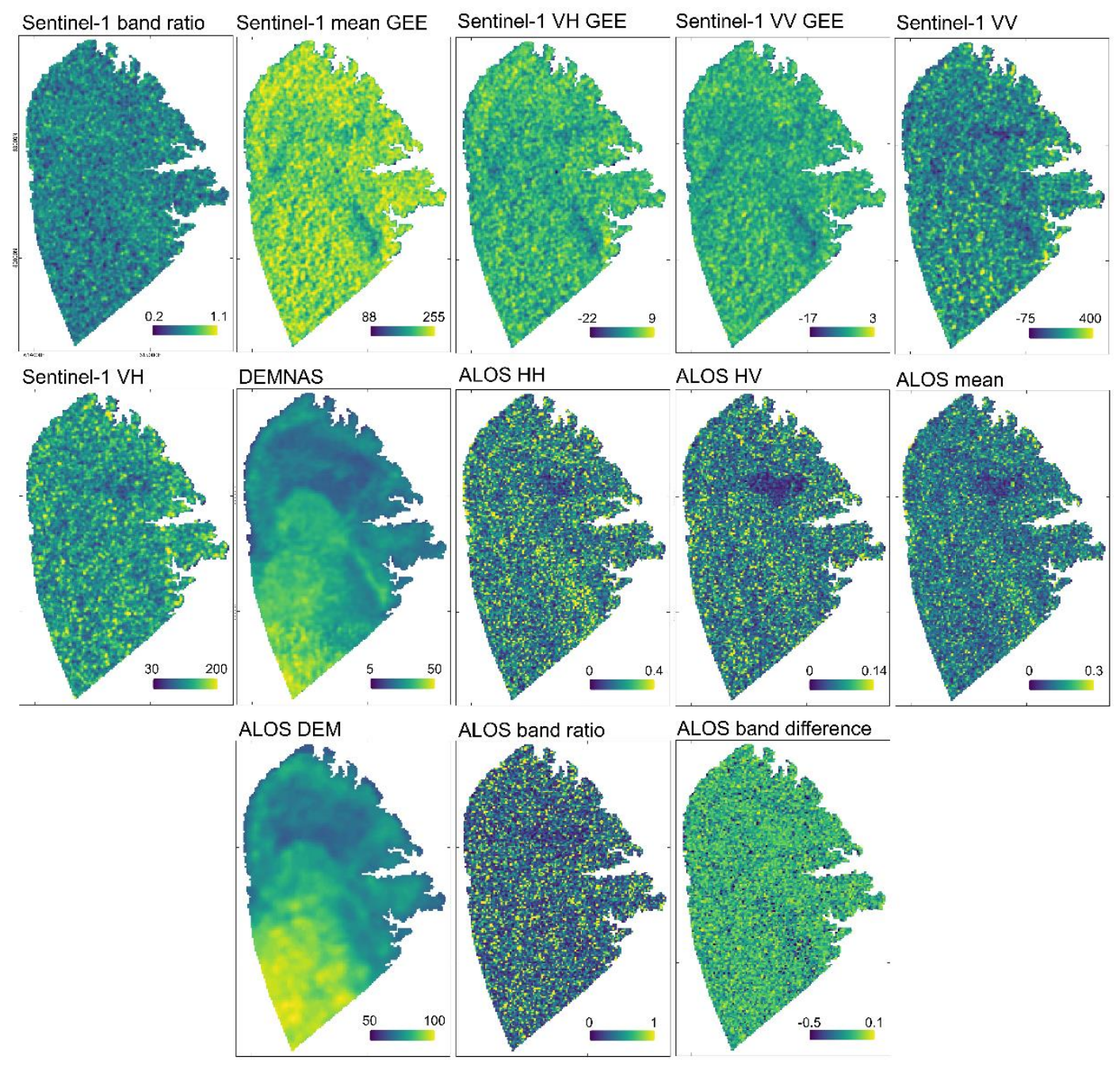

Fig. 2. Parameters used in peat thickness modeling.

Based on RMSE values, all of our models achieved an overall error of less than $0.6 \mathrm{~m}$. This accuracy is much higher than the previous study with a range of RMSE between 1.8 to $2.8 \mathrm{~m}$ (Rudiyanto et al., 2016). It is mainly due to the undisturbed peatlands in our study area, compared to highly degraded peatlands in a previous study in Bengkalis Island (Rudiyanto et al., 2016). The variability was less complex than degraded peatlands, where anthropogenic variables such as land cover need to be considered in the modeling. Therefore, our methods can be adapted to cover a larger area in undegraded tropical peatlands.

The mean peat thickness value based on the RF model (mean $=1.877 \mathrm{~m}$ ) is far below the average peat thickness mapped by Ruwaimana et al., (2020) at $5.16 \pm 2.66 \mathrm{~m}$ in Upper Kapuas Basin, where includes LSNP area. The high discrepancy is mainly due to the small area chosen for this study that does not cover a whole peat dome. The thicker peat is possibly located in the middle of the dome that is not mapped in this study. Spatial information of peat thickness is crucial to be the evidence to determine whether the peatlands can be used for cultivation or should be protected. According to the Ministerial Regulation No. 14 of 2017 concerning Inventory and Determination of the Function of Peat, peatlands with thickness less than $3 \mathrm{~m}$ are allowed for development, whereas conservation should be implemented for above $3 \mathrm{~m}$ thick peatlands. 

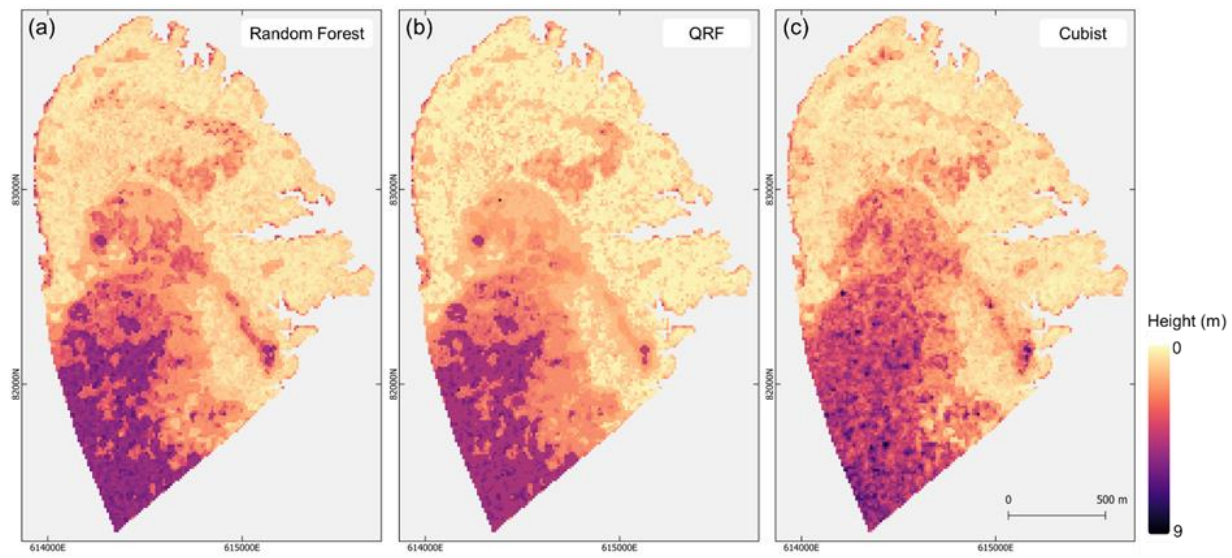

Fig. 3. Peat thickness modeled by (a) Random Forest, (b) Quantile Regression Forests, and (c) Cubist.

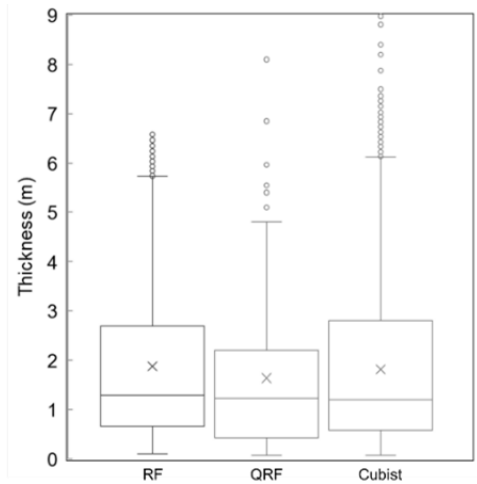

Fig. 4. Boxplots showing the distribution of thickness estimates based on machine learning models.

Table 2.

Root mean square error (in meter) and coefficient of determination values of peat thickness models.

\begin{tabular}{|c|c|c|}
\hline Methods & $\begin{array}{c}\text { Root mean square error } \\
\text { (RMSE) }\end{array}$ & $\begin{array}{c}\text { Coefficient of determination } \\
\left(\mathbf{R}^{\mathbf{2}}\right)\end{array}$ \\
\hline Random Forest & 0.483 & 0.786 \\
\hline Quantile Regression Forests & 0.544 & 0.729 \\
\hline Cubist & 0.756 & 0.514 \\
\hline
\end{tabular}

Based on our results, $79.18 \%$ of the areas have a thickness of less than $3 \mathrm{~m}$. However, it could not be generalized for the entire LSNP, since we only took a small area for the case study. Moreover, LSNP is a national park that was regulated to be a protected area, hence any land conversion is restricted regardless of the peat thickness.

\subsection{Variable importance for peat thickness modeling}

The importance level of variables used in modeling can be seen in Fig. 5. The variable of DEMNAS is highest among the others in all models (RF, QRF, and Cubist), followed by ALOS DEM. DEMNAS dominated the most in RF model, where the importance values of other variables are less than 10. In QRF model, ALOS DEM still contributed high in the modeling that exhibits the importance value of 50. The more distributed importance is shown by Cubist modeling. Despite DEMNAS and ALOS DEM representing surface elevation (Julzarika \& Harintaka, 2019), both still achieved the highest importance. The differences of both DEM data are the sources and spatial 
resolution. ALOS DEM is the up-sampled data from 1 arc-second (30 m) Shuttle Radar Topography Mission (SRTM) DEM acquired in 2000 (Alaska Satellite Facility, 2019). The IFSAR data used for generating DEMNAS has a higher spatial resolution, i.e., $5 \mathrm{~m}$ which was then resampled to $8.25 \mathrm{~m}$ to seamlessly produce a national DEM, with a more recent acquisition date in 2005. Therefore, DEMNAS could attain a higher score of variable importance than ALOS DEM.

The superior importance of DEM follows research conducted by Rudiyanto et al., (2018) that elevation is one of the important parameters in modeling peat thickness. Visually, a positive relationship was also observed that the higher the height, the thicker the peat. The general characteristic of peatlands in South-East Asia is a convex-dome shape, describing the higher elevation towards the center of the dome (Takada et al., 2016). Since peatlands were formed in the depression area, peats could be concentrated in the center and a biconvex form was shaped. However, further investigation should be conducted since the mounds of underlaying mineral soils may vary while the elevation of peat domes is smoother (Nasrul et al., 2020).

(a) Random Forest

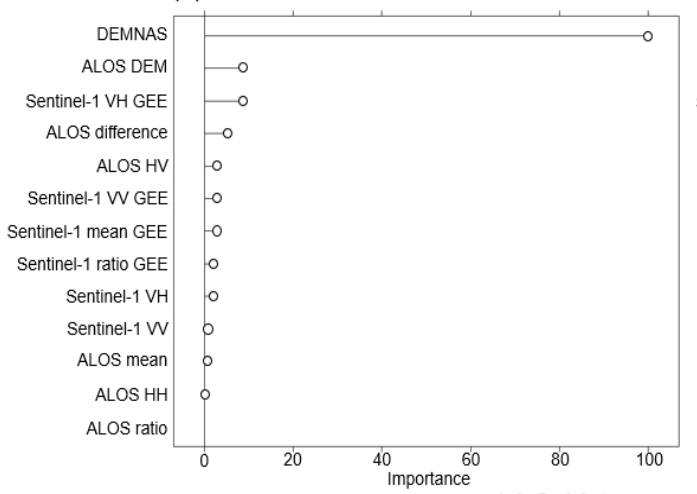

(c) Cubist

\section{(b) Quantile Regression Forests}

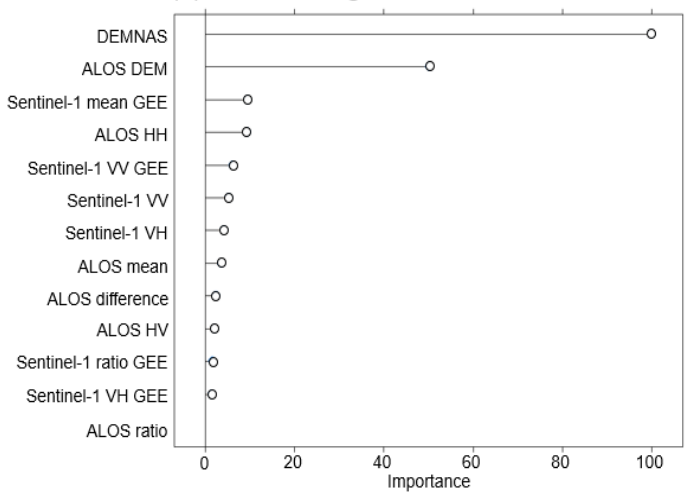

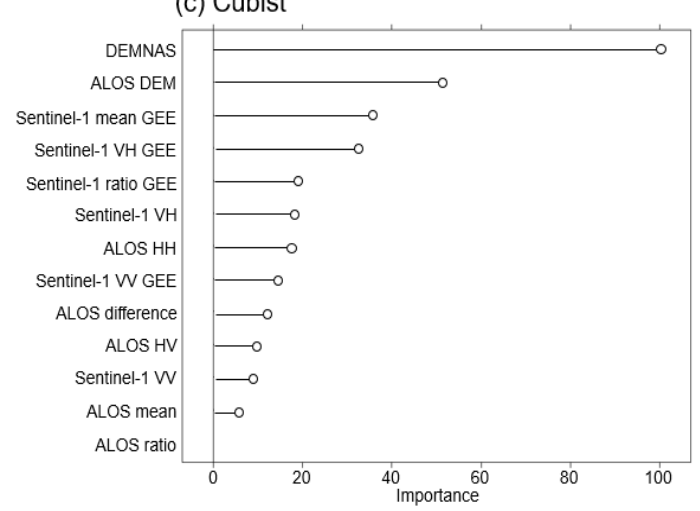

Fig. 5. Variable importance in (a) Random Forest, (b) Quantile Regression Forests, and (c) Cubist models.

The backscatter value of the radar image is less influential in modeling the thickness of the peat because the radar images (C- and L-band for Sentinel-1 and ALOS PALSAR, respectively) are unable to penetrate the vegetation coverage on the peatland. Overall, although working at C-band, the importance values of Sentinel-1 are higher than ALOS PALSAR, even the ratio calculation of ALOS data has zero importance in all models. For instance, P-band SAR data could penetrate deeper to the forest floor, yet the P-band satellite is currently under development (Meyer, 2019). BIOMASS mission carrying P-band (Quegan et al., 2019) and NISAR with S- and L-band (Rosen \& Kumar, 2021) that will be launched in upcoming years should be considered for future studies in peat thickness modeling. 


\subsection{Estimating spatial distribution of below-ground carbon stock}

Carbon stock was calculated using Equation 1 with the input of the best peat thickness model derived from RF regression. Fig. 6 illustrates the estimated below-ground carbon stock derived from the best model (Random Forest) of peat thickness (Fig. 6a), presented with the standard deviation map (Fig. 6b) and the boxplot showing the data distribution (Fig. 6c). Visually, the spatial distribution of carbon stock is the same as the peat thickness with different values as illustrated in Fig. 6a. The total volume of peat in the study area is $5,112,687 \mathrm{~m}^{3}$ considering the pixel size of $12.5 \mathrm{~m}$. The standard deviation of the carbon stock estimate was also quantified to show the uncertainty and variability (Fig. 6b). A total of $0.337 \pm 0.106 \mathrm{Mt}$ below ground carbon was predicted in the study area. Calculated based on the total area (272.33 ha), carbon concentration reached $1237.2 \pm 390.5 \mathrm{Mg}$ $\mathrm{ha}^{-1}$. This value is half the best estimate of peat carbon concentration in the country at $2772 \mathrm{Mg} \mathrm{ha}^{-1}$ (Page et al., 2011), mainly because of the low depth peat of the chosen study area. The whole Upper Kapuas Basin was estimated to store $2790 \pm 1440 \mathrm{Mg}$ of carbon in every hectare (Ruwaimana et al., 2020). This motivates future studies to apply a similar method to upscale the area covering at least one peat dome.
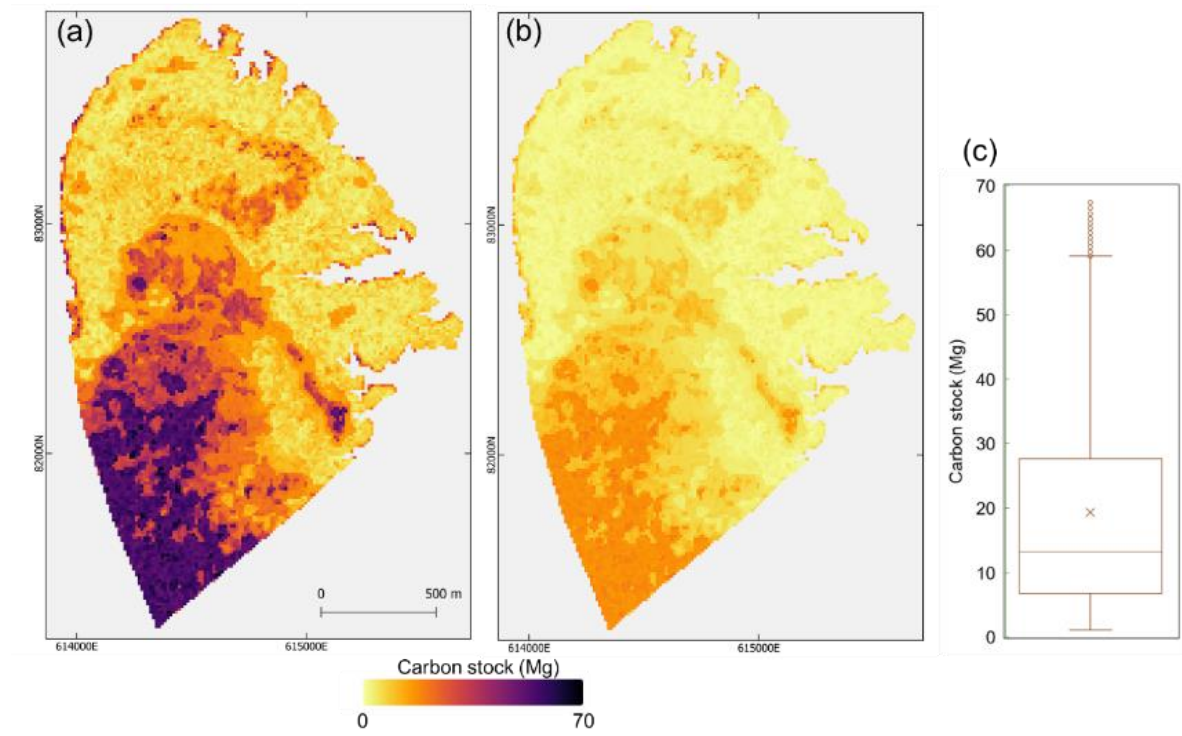

Fig. 6. (a) Estimated carbon stock, (b) its standard deviation based on peat thickness model, and (c) a boxplot presenting the data distribution.

\section{CONCLUSION}

We demonstrated machine learning methods for peat thickness mapping using elevation data and synthetic aperture radar (SAR) satellite imageries. Random Forest (RF) regression outperformed the results of Quantile Random Forests (QRF) and Cubist methods based on accuracy assessment with an RMSE of $0.483 \mathrm{~m}$ and an $\mathrm{R}^{2}$ of 0.786 . Among 13 variables, two elevation data (i.e., DEMNAS and ALOS DEM) are the most important features to model peat thickness. The longer wavelength of SAR data (e.g., P-band) should be explored to see the significance compared to C- and L-band data that did not show considerable contributions to the modeling. Based on the best method (RF regression), our results showed the mean peat thickness is $1.877 \mathrm{~m}$ with a total peat volume at $5,112,687 \mathrm{~m}^{3}$. We estimated a total carbon of $0.337 \pm 0.106 \mathrm{Mt}$ in the study area with a carbon concentration of $1237.2 \pm 390.5 \mathrm{Mg} \mathrm{ha}^{-1}$. The low carbon centration per area is due to the low peat depth in the selected study area that does not cover the whole peat dome. 


\section{R E F E R E N C E S}

Alaska Satellite Facility. (2019). ALOS PALSAR - Radiometric Terrain Correction. https://asf.alaska.edu/datasets/derived-data-sets/alos-palsar-rtc/alos-palsar-radiometric-terrain-correction/

Altdorff, D., Bechtold, M., van der Kruk, J., Vereecken, H., \& Huisman, J. A. (2016). Mapping peat layer properties with multi-coil offset electromagnetic induction and laser scanning elevation data. Geoderma, 261, 178-189. https://doi.org/10.1016/j.geoderma.2015.07.015

Anda, M., Ritung, S., Suryani, E., Sukarman, Hikmat, M., Yatno, E., Mulyani, A., Subandiono, R. E., Suratman, \& Husnain. (2021). Revisiting tropical peatlands in Indonesia: Semi-detailed mapping, extent and depth distribution assessment. Geoderma, 402, 115235. https://doi.org/10.1016/j.geoderma.2021.115235

Anderson, J. A. R. (1964). The structure and development of the peat swamps of Sarawak and Brunei. J Trop Geogr, 18, 7-16.

Anshari, G., Peter Kershaw, A., \& van der Kaars, S. (2001). A Late Pleistocene and Holocene pollen and charcoal record from peat swamp forest, Lake Sentarum Wildlife Reserve, West Kalimantan, Indonesia. Palaeogeography, Palaeoclimatology, Palaeoecology, 171(3-4), 213-228. https://doi.org/10.1016/S0031-0182(01)00246-2

Bourgeau-Chavez, L. L., Endres, S. L., Graham, J. A., Hribljan, J. A., Chimner, R. A., Lillieskov, E. A., \& Battaglia, M. J. (2018). Mapping Peatlands in Boreal and Tropical Ecoregions. In Comprehensive Remote Sensing (pp. 24-44). Elsevier. https://doi.org/10.1016/B978-0-12-409548-9.10544-5

Breiman, L. (2001). Random Forests. Machine Learning, 45(1), 5-32. https://doi.org/10.1023/A:1010933404324

Dargie, G. C., Lewis, S. L., Lawson, I. T., Mitchard, E. T. A., Page, S. E., Bocko, Y. E., \& Ifo, S. A. (2017). Age, extent and carbon storage of the central Congo Basin peatland complex. Nature, 542(7639), 86-90. https://doi.org/10.1038/nature21048

Dias, S. H. B., Filgueiras, R., Fernandes Filho, E. I., Arcanjo, G. S., Silva, G. H. da, Mantovani, E. C., \& Cunha, F. F. da. (2021). Reference evapotranspiration of Brazil modeled with machine learning techniques and remote sensing. PLOS ONE, 16(2), e0245834. https://doi.org/10.1371/journal.pone.0245834

Dohong, A., Aziz, A. A., \& Dargusch, P. (2018). Carbon emissions from oil palm development on deep peat soil in Central Kalimantan Indonesia. Anthropocene, 22, 31-39. https://doi.org/10.1016/j.ancene.2018.04.004

Geospatial Information Agency. (2018). DEMNAS. https://tanahair.indonesia.go.id/demnas/\#/

Giesen, W. (1987). Giesen (1987)_Danau Sentarum Wildlife Reserve-Inventory Ecology and Management Guidelines. World Wildlife Fund.

Giesen, W., \& Anshari, G. Z. (2018). Danau Sentarum National Park (Indonesia). In C. M. Finlayson, G. R. Milton, R. C. Prentice, \& N. C. Davidson (Eds.), The Wetland Book (pp. 1841-1850). Springer Netherlands. https://doi.org/10.1007/978-94-007-4001-3_44

Hil, G. (2020). Better Management Through Measurement: Integrating Archaeological Site Features into a GIS-Based Erosion and Sea Level Rise Impact Assessment-Blueskin Bay, New Zealand. The Journal of Island and Coastal Archaeology, 15(1), 104-126. https://doi.org/10.1080/15564894.2018.1531331

Holden, N. M., \& Connolly, J. (2011). Estimating the carbon stock of a blanket peat region using a peat depth inference model. CATENA, 86(2), 75-85. https://doi.org/10.1016/j.catena.2011.02.002

Houborg, R., \& McCabe, M. F. (2018). A hybrid training approach for leaf area index estimation via Cubist and random forests machine-learning. ISPRS Journal of Photogrammetry and Remote Sensing, 135, 173188. https://doi.org/10.1016/j.isprsjprs.2017.10.004

Jaenicke, J., Rieley, J. O., Mott, C., Kimman, P., \& Siegert, F. (2008). Determination of the amount of carbon stored in Indonesian peatlands. Geoderma, 147(3-4), 151-158. https://doi.org/10.1016/j.geoderma.2008.08.008

Julzarika, A. \& Harintaka. (2019). Indonesian DEMNAS: DSM or DTM? 2019 IEEE Asia-Pacific Conference on Geoscience, Electronics and Remote Sensing Technology (AGERS), 31-36. https://doi.org/10.1109/AGERS48446.2019.9034351 
Keaney, A., McKinley, J., Graham, C., Robinson, M., \& Ruffell, A. (2013). Spatial statistics to estimate peat thickness using airborne radiometric data. Spatial Statistics, 5, 3-24.

https://doi.org/10.1016/j.spasta.2013.05.003

Kuhn, M., \& Johnson, K. (2013). Applied Predictive Modeling. Springer New York. https://doi.org/10.1007/978-1-4614-6849-3

Kuhn, M., Weston, S., Keefer, C., Coulter, N., \& Quinlan, R. (2021). Package “Cubist” (0.3.0) [R].

Liaw, A., \& Wiener, M. (2002). Classification and regression by randomForest. $R$ News, 2(3), 18-22.

McBratney, A. B., Mendonça Santos, M. L., \& Minasny, B. (2003). On digital soil mapping. Geoderma, 117(1-2), 3-52. https://doi.org/10.1016/S0016-7061(03)00223-4

Meinshausen, N. (2006). Quantile Regression Forests. Journal of Machine Learning Research, 7, 983-999.

Melling, L. (2016). Peatland in Malaysia. In M. Osaki \& N. Tsuji (Eds.), Tropical Peatland Ecosystems (pp. 59-73). Springer Japan. https://doi.org/10.1007/978-4-431-55681-7_4

Meyer, F. (2019). Spaceborne Synthetic Aperture Radar: Principles, Data Access, and Basic Processing Techniques. https://doi.org/10.25966/EZ4F-MG98

Mitra, S., Wassmann, R., \& Vlek, P. L. G. (2005). An appraisal of global wetland area and its organic carbon stock. Current Science, 88(1), 25-35.

Nasrul, B., Maas, A., Utami, S. N. H., \& Nurudin, M. (2020). The relationship between surface topography and peat thickness on Tebing Tinggi Island, Indonesia. Mires and Peat, 26, 1-21. https://doi.org/10.19189/MaP.2019.OMB.StA.1811

Noi, P., Degener, J., \& Kappas, M. (2017). Comparison of Multiple Linear Regression, Cubist Regression, and Random Forest Algorithms to Estimate Daily Air Surface Temperature from Dynamic Combinations of MODIS LST Data. Remote Sensing, 9(5), 398. https://doi.org/10.3390/rs9050398

Page, S. E., Rieley, J. O., \& Banks, C. J. (2011). Global and regional importance of the tropical peatland carbon pool. Global Change Biology, 17(2), 798-818. https://doi.org/10.1111/j.1365-2486.2010.02279.x

Page, S. E., Wüst, R. A. J., Weiss, D., Rieley, J. O., Shotyk, W., \& Limin, S. H. (2004). A record of Late Pleistocene and Holocene carbon accumulation and climate change from an equatorial peat bog(Kalimantan, Indonesia): Implications for past, present and future carbon dynamics. Journal of Quaternary Science, 19(7), 625-635. https://doi.org/10.1002/jqs.884

Quegan, S., Le Toan, T., Chave, J., Dall, J., Exbrayat, J.-F., Minh, D. H. T., Lomas, M., D’Alessandro, M. M., Paillou, P., Papathanassiou, K., Rocca, F., Saatchi, S., Scipal, K., Shugart, H., Smallman, T. L., Soja, M. J., Tebaldini, S., Ulander, L., Villard, L., \& Williams, M. (2019). The European Space Agency BIOMASS mission: Measuring forest above-ground biomass from space. Remote Sensing of Environment, 227, 44-60. https://doi.org/10.1016/j.rse.2019.03.032

Quinlan, J. R. (1993). Combining instance-based and model-based learning. 236-243.

Quinlan, J. R. (1992). Learning with continuous classes. 92, 343-348.

Ribeiro, K., Pacheco, F. S., Ferreira, J. W., Sousa-Neto, E. R., Hastie, A., Krieger Filho, G. C., Alvalá, P. C., Forti, M. C., \& Ometto, J. P. (2021). Tropical peatlands and their contribution to the global carbon cycle and climate change. Global Change Biology, 27(3), 489-505. https://doi.org/10.1111/gcb.15408

Rieley, J., \& Page, S. (2016). Tropical Peatland of the World. In M. Osaki \& N. Tsuji (Eds.), Tropical Peatland Ecosystems (pp. 3-32). Springer Japan. https://doi.org/10.1007/978-4-431-55681-7_1

Rosen, P. A., \& Kumar, R. (2021). NASA-ISRO SAR (NISAR) Mission Status. 2021 IEEE Radar Conference (RadarConf21), 1-6. https://doi.org/10.1109/RadarConf2147009.2021.9455211

Rudiyanto, Minasny, B., Setiawan, B. I., Arif, C., Saptomo, S. K., \& Chadirin, Y. (2016). Digital mapping for cost-effective and accurate prediction of the depth and carbon stocks in Indonesian peatlands. Geoderma, 272, 20-31. https://doi.org/10.1016/j.geoderma.2016.02.026

Rudiyanto, Minasny, B., Setiawan, B. I., Saptomo, S. K., \& McBratney, A. B. (2018). Open digital mapping as a cost-effective method for mapping peat thickness and assessing the carbon stock of tropical peatlands. Geoderma, 313, 25-40. https://doi.org/10.1016/j.geoderma.2017.10.018

Ruwaimana, M., Anshari, G. Z., Silva, L. C. R., \& Gavin, D. G. (2020). The oldest extant tropical peatland in the world: A major carbon reservoir for at least 47000 years. Environmental Research Letters, 15(11), 114027. https://doi.org/10.1088/1748-9326/abb853

Silvestri, S., Knight, R., Viezzoli, A., Richardson, C. J., Anshari, G. Z., Dewar, N., Flanagan, N., \& Comas, X. (2019). Quantification of Peat Thickness and Stored Carbon at the Landscape Scale in Tropical Peatlands: A Comparison of Airborne Geophysics and an Empirical Topographic Method. Journal of Geophysical Research: Earth Surface, 124(12), 3107-3123. https://doi.org/10.1029/2019JF005273 
Supardi, Subekty, A. D., \& Neuzil, S. G. (1993). General geology and peat resources of the Siak Kanan and Bengkalis Island peat deposits, Sumatra, Indonesia. In Geological Society of America Special Papers (Vol. 286, pp. 45-62). Geological Society of America. https://doi.org/10.1130/SPE286-p45

Takada, M., Shimada, S., \& Takahashi, H. (2016). Tropical Peat Formation. In M. Osaki \& N. Tsuji (Eds.), Tropical Peatland Ecosystems (pp. 127-135). Springer Japan. https://doi.org/10.1007/978-4-431-556817_8

Umarhadi, D. A., Widyatmanti, W., Kumar, P., Yunus, A. P., Khedher, K. M., Kharrazi, A., \& Avtar, R. (2021). Tropical peat subsidence rates are related to decadal LULC changes: Insights from InSAR analysis. Science of The Total Environment, 151561. https://doi.org/10.1016/j.scitotenv.2021.151561

Verrelst, J., Camps-Valls, G., Muñoz-Marí, J., Rivera, J. P., Veroustraete, F., Clevers, J. G. P. W., \& Moreno, J. (2015). Optical remote sensing and the retrieval of terrestrial vegetation bio-geophysical properties - A review. ISPRS Journal of Photogrammetry and Remote Sensing, 108, 273-290. https://doi.org/10.1016/j.isprsjprs.2015.05.005

Warren, M. W., Kauffman, J. B., Murdiyarso, D., Anshari, G., Hergoualc'h, K., Kurnianto, S., Purbopuspito, J., Gusmayanti, E., Afifudin, M., Rahajoe, J., Alhamd, L., Limin, S., \& Iswandi, A. (2012). A costefficient method to assess carbon stocks in tropical peat soil. Biogeosciences, 9(11), 4477-4485. https://doi.org/10.5194/bg-9-4477-2012

Wei, Y., Kehm, R. D., Goldberg, M., \& Terry, M. B. (2019). Applications for Quantile Regression in Epidemiology. Current Epidemiology Reports, 6(2), 191-199. https://doi.org/10.1007/s40471-01900204-6

Yu, Z., Loisel, J., Brosseau, D. P., Beilman, D. W., \& Hunt, S. J. (2010). Global peatland dynamics since the Last Glacial Maximum. Geophysical Research Letters, 37(13). https://doi.org/10.1029/2010GL043584

Zhou, J., Li, E., Wei, H., Li, C., Qiao, Q., \& Armaghani, D. J. (2019). Random Forests and Cubist Algorithms for Predicting Shear Strengths of Rockfill Materials. Applied Sciences, 9(8), 1621.

https://doi.org/10.3390/app9081621 